\title{
The Dynamic Analysis on Impacts of Education against Poverty Reduction
}

\author{
Sri Herianingrum, Sri Iswati, Muslich Anshori \\ Postgraduate School \\ Universitas Airlangga \\ Surabaya, Indonesia \\ sri.herianingrum@feb.unair.ac.id \\ iswati.feua@gmail.com \\ slich@unair.ac.id
}

\begin{abstract}
The role of education in poverty reduction is very important. If a person does not have sufficient education and comes from an unfortunate family, it is hard for them to find a decent job that can improve the welfare of their family. This can be compared with a person coming from a poor family but having adequate education; it will be easier for them to find decent work. This research examines the dynamic relationship between education and poverty reduction using a co-integration and causality test using Stata. The long-term relationship between the variables for a case study in Indonesia with cointegration explains that, in the long run, the variables of education and poverty do not affect each other. Further data for the case in the context of Malaysia shows that in the long-term, education and poverty variables are co-integrated or affect each other. The other test is the relationship between the variables for the case in Indonesia with a Granger Causality test, which can be concluded that the poverty variables affect the education variables, and vice versa. Based on these results, we can explain that there are two way that the relationship between poverty and education works. The results of the next data set is for the case in Malaysia. We obtained poverty test results that do not affect the education variables and education variables that do affect the variable of poverty. It can be concluded that there is a one-way relationship from education to poverty.
\end{abstract} test.

Keywords-education; poverty; cointegration test; causality

\section{INTRODUCTION}

One of the causes of rising poverty is the decline in purchasing power, which has an impact on the ability to fulfil basic needs. The lowered ability of the community to fulfil its basic needs means that the community can be regarded as being poor. According to the standards of the United Nations Development Program (UNDP), a person is called poor if his expenses are below $\$ 2$ per day.

The percentage of poverty during the economic crisis in 1998 drastically increased, even more at that time given the amount of people able to pursue education to university level compared with those who could only pursue a level of elementary, junior, or senior high school education. The low level of community education makes it harder for the community to improve their living standards. This is due to the need of better-paying work which requires that the prospective worker has a pre-determined level of education, such as a prospective worker in a multi-national company being required to have a bachelor's degree. Under these conditions, only certain circles can apply for job vacancies. The unevenness of the access to education services can be due to the cost of education which is considered too expensive by some people, especially for the poor, making it difficult for the poor to get out of the poverty trap.

The role of education in eradicating poverty from society is very important. The role this plays is that if a person who is assessed does not have sufficient education and the person comes from an unfortunate family, they will have difficulty finding a decent job that can improve the welfare of their family. When compared with the same person coming from a poor family but with an adequate education, it is easier for them to find decent work that can improve the welfare of the family.

The role of the government is needed in realising the distribution of education, as one of the main organisers and for the quality assurance of public education. As a form of government responsibility in improving the welfare of the community through the education sector, the government has pooled a number of funds that must be used in the education sector.

Based on the background and identification of problems in this research study, the issues that will be discussed are:

1. Is there a long-term relationship between the variables of Islamic education and poverty reduction in Indonesia?

2. Is there a long-term relationship between the variables of Islamic education and poverty reduction in Malaysia?

3. Is there a causal relationship between the variables of Islamic education and poverty reduction in Indonesia?

4. Is there a causal relationship between the variables of Islamic education and poverty reduction in Malaysia?

\section{LITERATURE REVIEW}

\section{A. Poverty}

According to the United Nations Development Program (UNDP) in Amalia (2010), a person in poverty is someone who is categorised as poor if they have expenses under US \$ 2 
per day. UNDP in Amalia (2010) defines poverty as a condition in which a person loses three main things:

a. Life

More than 30 percent of the population in the poorest countries live less than forty years.

b. Basic education

Measured from the percentage of the adult population who are illiterate.

c. Economic determination

Measured from the percentage of people who do not have access to health services and clean water plus the percentage of children aged under five years who are underweight.

Poverty in the Islamic perspective according to Mahzab Hanafi in Amalia (2010), is a person who has a permanent job but cannot fulfill their daily needs. Meanwhile, according to the Mahzab Shafi'i, Hambali, and Maliki in Amalia (2010), the poor are those who have property or income worthy to fulfil their needs and others who have this responsibility but cannot fully fulfil it.

\section{B. Poverty Criteria}

The poverty criteria used in each country is different. Differences in the poverty criteria are caused by geographic conditions or differences in the location of each country as well as the standard of living (Amalia, 2010). In Indonesia, the institution that examines the poverty line is the Central Bureau of Statistics (BPS). The Central Bureau of Statistics determines the poverty line using the amount of rupiah spent per capita every month to fulfil the minimum food and nonfood needs of an individual (Amalia, 2010). As for the minimum food intake needs benchmark, 2,100 calories per day has already been mentioned by Amalia (2010).

The use of BPS in determining the poverty line using the amount of rupiah spent per capita a month to meet the minimum food and non-food needs is in the perspective of Islam. The line of poverty in the Islamic perspective as mentioned by Ryandono (2008: 46) in Amalia (2010), is that a person will become Muzakki if their possessions have reached $n i s a b$ and the person is categorised as prosperous.

\section{Education}

According Soyomukti (2008: p. 29) education is still believed to be a process that is able to pump the productive forces of our nation. Productive power according to Soyomukti (2008: 31 ) is society's ability to produce a form of action and product that is technological or intellectual related to economics. In general, people with productive power are better known as science and technology. According to Soyomukti (2008: p. 31) as society progresses in science and technology, so do more individuals get to experience the ease of life, prosperity, and the ease to express their humanity.

One example of this ease of life is when a farmer who only understands reading and writing without ever learning anything else, such as learning how to produce abundant crops, will be different in his life with a literate farmer who learns how to produce abundant crops. By learning how to produce an abundant harvest, the farmer indirectly learns a lot. Starting from what tools are used to harvesting the harvest, to whatever factors are involved that can support and inhibit the harvest.

The higher a farmer is mastering the field of his work through the process of education or learning, conducted by the self and learning results from others, the more this will indirectly improve the welfare of the farmer. The welfare of the farmer will be achieved by the way that the farmer opens a course on agricultural science and collects a fee or proceeds from selling his inventions. These can be the results of his study of agricultural science, and this opens up many more ways to improve his welfare.

Increasing someone's welfare will be achieved if one of the media they are exposed to is education that is not monopolised by a person or a group of people. A monopoly on education will occur if the person deemed the best in solving the problems of life and facing the challenges of nature and enemies outside of the tribe (community) tends to be given authority and trust by members of the society as in Soyomukti (2008: p. 10-11). This is where the role of the government comes in to ensure the quality of education and for all people to be educated to a high level.

\section{METHODOLOGY}

\section{A. Research approach}

The approach used in this research study is a descriptive quantitative approach. Descriptive quantitative research is a problem related to the question of the existence of independent variables, to do with one or more variables (Anshori, 2009). The quantitative approach is done by using an econometric model.

The purpose of the method of quantitative research is to show the influence between the variables, seeking a theory and looking for generalisations that have predictive value (Sugiyono, 2012: p. 14). The quantitative approach uses a combined method of econometric analysis, mathematical analysis, economic theory and statistics.

\section{B. Identify Variables}

The research variables can be interpreted as being temporary answers to the research problem. The truth should be tested empirically (Nazir, 2003). The hypothesis is used to describe the relationship between two variables, namely the causal and result variables, and there is also a comparison of one variable from within two samples (Arikunto, 2002). The research variable is the object chosen by the researcher to be researched, and from which to draw the conclusion of the variable research (Sugiono, 2012: p. 38).

The variables used in this study are:

1. Independent variables are variables that affect others, or are variable causes (Anshori and Iswati, 2009: p. 57). The 
independent variable in this research is education, which consists of education SD/MI, SMP/Tsanawiyah, and SMU/Aliyyah.

2. The dependent variables are also referred to as output variables, criteria and consequences (Anshori, and Iswati, 2009: p. 58). The dependent variable in this research study is poverty.

\section{DISCUSSION OF THE RESULTS}

\subsection{Long-term relationship between the Islamic education} sector and poverty reduction in Indonesia

The results of the statistical tests show that there is no long-term relationship. This is evidenced by the results obtained from the Johansen co-integration test. The cointegration test results in this research are:

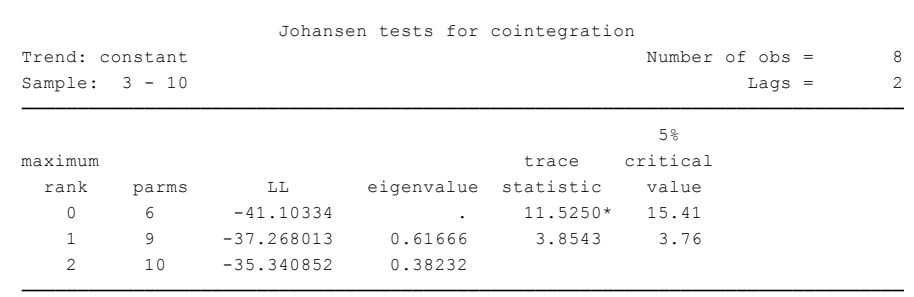

Source: Co-integration Test Results STATA 13, processed

Picture 1. Co-integration Test Results in Indonesia

From Picture 1, it can be seen that the results obtained from the results of the Islamic education variable and poverty are not co-integrated in the long-term, which is indicated by the trace statistic being less than the critical value of 5\%. So in the long run, the variables will not affect each other.

\subsection{Long-term relationship between Islamic education sector and poverty reduction in Malaysia}

There is a long-term relationship between the Islamic education sector and poverty reduction in Malaysia, clarified with the results obtained from the Johansen co-integration test. The co-integration test results in this research are:

\begin{tabular}{cccccc}
\multicolumn{1}{c}{ Johansen tests for cointegration } \\
Trend: constant \\
Sample: $3-10$
\end{tabular}

Source: Co-integration Test Results STATA 13, processed Picture 2. Co-integration Test Results in Malaysia

From Picture 2, the results we can see that the co-integration test using the Johansen Test obtained results that show that the variable of Islamic education and poverty are co-integrated in the long-term, which is indicated by the trace statistic being greater than the critical value of $5 \%$. So in the long run, the variables will affect each other.
4.3 The causality link between the Islamic education sector and poverty reduction in Indonesia

The results obtained from this research are:

Granger causality Wald tests

\begin{tabular}{|rr|rrr|}
\hline Equation & Excluded & chi2 & df Prob > chi2 \\
\hline poverty & education & $\begin{array}{l}6.979 \\
\text { ALI }\end{array}$ & $\begin{array}{l}6 \\
6.979\end{array}$ & $\begin{array}{l}0.031 \\
0.031\end{array}$ \\
\hline poverty & poverty & 8.289 & 2 & 0.016 \\
education & ALL & 8.289 & 2 & 0.016 \\
\hline
\end{tabular}

Sources: Results of STATA 13 Causality Test, processed Picture 3. Causality Test Result in Indonesia

From Picture 3, the test results can be used to conclude that:

a. The variables of poverty affect the education variables.

b. The variable of education affects the poverty variable.

Therefore, there is a two way relationship between poverty and education, and vice versa.

4.4 The causality relationship between the Islamic education sector and poverty reduction in Malaysia

The results obtained from this research are:

Granger causality Wald tests

\begin{tabular}{|rr|ccc|}
\hline Equation & Excluded & chi2 & df Prob > chi2 \\
\hline poverty & education & .58689 & 2 & $\begin{array}{l}0.746 \\
0.746\end{array}$ \\
poverty & ALL & .58689 & 2 & .740 \\
\hline education & poverty & 17.385 & 2 & 0.000 \\
education & ALL & 17.385 & 2 & 0.000 \\
\hline
\end{tabular}

Sources: Results of STATA 13 Causality Test, processed Picture 4. Causality Test Result in Malaysia

From the test results above, it can be concluded that:

a. The poverty variable does not affect the education variable.

b. Education affects the poverty variable.

So there is one way causality from education to poverty.

The results of this research generally show that long-term Islamic education is represented through education from madrasah to tsanawiyah positively and is significantly related to poverty reduction in Indonesia. This shows empirically that the presence of Islamic education is not only theoretically and ideologically able to boost the economic activity of a country, but this theory can be proven empirically within the scope of the education and economic sectors in Indonesia as well. Through the results of this study, Islamic education has effectively played its role as an educational institution that facilitates the mobilisation of human resources. Therefore, we can say that the government's policy to develop a comprehensive Islamic education system in Indonesia is considered to be effective as long as the development of the education sector and economic growth or the real sector remain strongly interconnected. This study also indicates that the improvement of the education infrastructure in Indonesia will provide benefits towards economic development and this 
is important in the long term for the development of the welfare of the people. The case study in Malaysia also used in this research is relatively more serious in the handling of education, planning, and equitable education that has materialised, so the progress and welfare of the community is more secure.

\section{Conclusions}

Based on the results of the statistical tests and discussion of the research, the conclusions of this research are:

a. There is no long-term relationship between the variables of Islamic education and poverty reduction in Indonesia. The percentage of Islamic education is still dominated by Madrasah and Tsanawiyah, so the majority of the population still do not have the skills required by most jobs.

b. There is a long-term relationship between the variables of Islamic education and poverty reduction in Malaysia. The percentage of Islamic education is evenly distributed at the education level of Aliyah and above. This means that education in Malaysia in the long run has been able to provide the skills required by the jobs to get people out of poverty.

c. There is a two way relationship between the variables of Islamic education and poverty reduction in Indonesia. Poverty affects Islamic education; the poor cannot afford education because the education grants have not been evenly distributed to the poor. Islamic education plays a role in Islam, which is relatively large in Indonesia in relation to basic education until and unless it is able to motivate and improve people's skills, so that education can reduce poverty.

d. There is a one way relationship between the variables of Islamic education and poverty reduction in Malaysia. Islamic education pursued by Malaysians fulfils the skills required by the job, so that it can help to reduce poverty in Malaysia.

\section{Acknowledgment}

Thank to Prof. Dr. Sri Iswati, SE, M.Si., Ak., Prof.Anwar, and Prof. Dina for their support, guidance and suggestions to make this research finished successfully.

\section{References}

[1] Abbas, Qaisar. Endogenous Growth and Human Capital: A Comparative Study of Pakistan and Sri Lanka. Hal. 987-1007. Pakistan: The Pakistan Development Review, 2001.

[2] Afzal, Muhammad et al. Relationship Between School Education and Economic Growth in Pakistan: ARDL Bounds Testing Approach to Cointegration. Vol. 48, No.1, Hal. 39-60. Pakistan: Pakistan Economic and Social Review, 2010.

[3] Agiomirgianakis, George Myron dan Dimitrios Ateriou. Human Capital and Economic Growth: Time Series Evidence from Greece. Yunani: Journal of Policy Modeling, 2001.

[4] Armstrong, Harvey dan Jim Taylor. Regional Economics and Policy. Edisi ketiga. Oxford: Blackwell Publishing, 2000.

[5] Amalia, Puspita Demy. Peran Lembaga Amil Zakat dalam Pemberdayaan Ekonomi Masyarakat Miskin. Surabaya. Skripsi tidak diterbitkan. Universitas Airlangga Surabaya, 2010.

[6] Bank Indonesia dan Pusat Pengkajian dan Pengembangan Ekonomi Islam Universitas Islam Indonesia. Ekonomi Islam. Jakarta: PT Raja Grafindo Persada, 2008.

[7] Chapra, Umer M. Ibn Khaldun's theory of development: Does it help explain the low performance of the present-day Muslim world?. The Journal of Socio-Economics Vol. 37, Hal 836-863, 2008.

[8] Chi, W. The Role of Human Capital in China's Economic Development: Review and New Evidence. Hal. 421-436. China Economic Review, 2008.

[9] Chaudhry, Muhammad Sharif. Sistem Ekonomi Islam Prinsip Dasar. Jakarta: Kencana Prenadamedia Grup, 2012.

[10] Effendi, Agus dan Bahruddin Fananny. Kajian Berbagai Mazhab. Bandung: PT Remaja Rosdakarya, 2008.

[11] Fauzia, Ika Yunia dan Abdul Kadir Riyadi. Prinsip Dasar Ekonomi Islam Perspektif Maqashid Al-Syariah. Jakarta: Kencana Prenadamedia Grup, 2014.

[12] Santoso, Singgih. Analisis SPSS pada Statistik Parametrik. Jakarta: PT. Elex Media Komputindo, 2012.

[13] Sholihin, Ahmad Ifham. Buku Pintar Ekonomi Syariah. Jakarta: PT Gramedia Pustaka Utama, 2010.

[14] Simorangkir, Iskandar. Pengantar Kebanksentralan: Teori dan Praktik di Indonesia. Depok: PT Raja Grafindo Persada, 2014.

[15] Suliyanto. Ekonometrika Terapan: Teori dan Aplikasi dengan SPSS. Yogyakarta: Andi Offset, 2011.

[16] Sugiyono. Metode Penelitian Kuantitatif, Kualitatif dan R\&D. Bandung: CV Alfabeta, 2014.

[17] Soyomukti, Nurani. Pendidikan Berperspektif Globalisasi. Yogyakarta: Ar-Ruzz Media, 2008.

[18] Tjiptoherijanto, Prijono dan Budhi Soesetyo. Ekonomi Kesehatan. Jakarta.:PT Rineka Cipta, 1994.

[19]www.bps.go.id 